\title{
PRODUCTION OF ENDOGLUCANASE BY THE NATIVE STRAINS OF STREPTOMYCES ISOLATES IN SUBMERGED FERMENTATION
}

\author{
Chellapandi P.*; Himanshu M. Jani \\ Biogas Research Centre, Gujarat Vidyapith, Gujarat, India
}

Submitted: October 12, 2007; Returned to authors for corrections: November 14, 2007; Approved: January 21, 2008.

\begin{abstract}
Cellulase is a complex enzyme system, commercially produced by filamentous fungi under solid-state and submerged cultivation. It has wide applicability in textile, food and beverage industry for effective saccharification process. In this study, cellulolytic enzyme activity, particularly endoglucanase of 26 Streptomyces strains isolated from garden soil was examined, including two isolates selected on the basis of potential cellulolytic activity on Bennett's agar medium. To enhance the endoglucanase formation in broth culture, different conditions including carbon and nitrogen sources, and growth conditions were tested. The maximum endoglucanase activity $(11.25-11.90 \mathrm{U} / \mathrm{mL})$ was achieved within $72-88 \mathrm{~h}$ in fermentation medium containing Tween-80, followed by phosphate sources. Both cellulolytic Streptomyces isolates gave almost equal quantity of enzyme in all trials. However the effect of medium ingredients on endoglucanase induction diverged with strains in some extent.
\end{abstract}

Key words: Endoglucanase, Streptomyces isolates, Submerged cultivation, Media optimization, Cellulase, CMCase

\section{INTRODUCTION}

Cellulase is an industrially important enzyme, which is extensively used for increasing yield of juice in food industry, decreasing discoloration and fuzzing effects of cloth in textile industry, strengthening and whitening of paper pulp in paper industry, and to bio-fuel generation through saccharification process $(2-3,15,23)$. Cellulose is composed of glucose units linked together by a 1.4-D- $\beta$ glycoside bond (8). Cellulase is a synergistic enzyme that is used to break up cellulose into glucose or other oligosaccharide compounds. It has three major components viz. endo 1.4- $\beta$-glucanase (E.C.3.2.1.4), exo 1.4- $\beta$ glucanase (E.C.3.2.1.91), and $\beta$-glucosidase (E.C.3.2.1.21), on which endoglucanase is known as a well recognized component (7).

Many cellulolytic aerobic and anaerobic bacteria (8) have been isolated from decomposed soil, $(9,14)$ for biotechnological applications. Furthermore, the production of this enzyme has been studied in many filamentous fungi, particularly in Trichoderma, Aspergillus, Fusariumn, and Penicillium groups $(15,17)$. Although, a little work has been done on bacterial cellulase and a limited attention is being on Streptomyces groups. Because of the production yield and stability of bacterial cellulases are comparatively lesser than fungal cellulases, a detailed study on exploitation of this enzyme from Streptomyces species have been hindered. However, soil isolates Streptomyces lividens (9), S. albaduncus (5-6), S. reticuli (16), Streptomyces sp. strain M7a \& strain M7b (17), and Streptomyces sp. F2621 (19) have already reported to produce extracellular endoglucanase significantly in optimized culture media using cellulose powder as carbon source under shaking conditions. Culture conditions, therefore, play a prominent role on formation of endoglucanase from bacteria $(10,11)$. Since, this present paper investigated how the different media ingredients and culture conditions would be influenced on native strains of Streptomyces isolates for enhancing endoglucanase yield.

*Corresponding Author. Mailing address: Department of Bioinformatics, School of Life Sciences, Bharathidasan University, Tiruchirappalli, 620024, Tamilnadu, India. Phone: +91-431-2407072; Fax: +91 431-2407045. E-mail: pchellapandi@gmail.com 


\section{MATERIALS AND METHODS}

\section{Sources of media and analytical chemicals}

All chemicals used were of analytical grade. Media and chemicals used in this study were purchased from HiMedia, Qualigen, and SD Fine Chemicals, India.

\section{Screening and isolation of cellulolytic Streptomycetes}

The microbial strains were isolated from decomposed garden soil in Gujarat Vidyapith, Sadra, India. Approximately $5 \mathrm{~g}$ soil was collected and diluted with $10 \mathrm{~mL}$ sterile distilled water, and then homogenized by constant shaking. The supernatant was collected after centrifugation at $6000 \mathrm{rpm}$ for $15 \mathrm{~min}$, which was further serial diluted with Bennett's broth containing the following in $\mathrm{g} / \mathrm{L}$ : Maltose, 10; N-Z amine, Type A, 2.0; Beef extract, 1.0; Yeast extract, 1.0, and $\mathrm{pH}$ was adjusted to 7.4. 0.1 $\mathrm{mL}$ of this diluted sample was inoculated on Bennett's agar medium supplemented with $1 \%(\mathrm{w} / \mathrm{w})$ cellulose, and then incubated at $30^{\circ} \mathrm{C}$ for $24 \mathrm{~h}$. Actinomycetes whose grow were vigorously appeared have selected for secondary screening in broth culture. Streptomyces spores were scrapped from plates and diluted with $1 \mathrm{~mL}$ sterile distilled water, homogenized. In 25 $\mathrm{ml}$ Bennett's broth incorporated with $1 \%(\mathrm{v} / \mathrm{v})$ Walsath cellulose, $1 \mathrm{~mL}$ of diluted Streptomyces spores were inoculated and incubated at $30^{\circ} \mathrm{C}$ for 3 days. According to potential cellulolytic activity in cell-free culture supernatant as assayed by method described below, 26 Streptomyces isolates were screened out of which two isolates with high CMCase activity have selected. These strains were preserved on the same agar medium at $4^{\circ} \mathrm{C}$ with periodic sub-culturing. Morphological and biochemical characteristics of these selected isolates were used for preliminary identification according to Bergey's manual.

\section{Production of endoglucanase in broth culture}

Two $\mathrm{mL}$ of sterile distilled water added to the four day old culture and slightly scratch with a loop to obtain spore suspension. $0.1 \mathrm{~mL}$ of this suspension was used as inoculum and transferred to $25 \mathrm{~mL}$ Bennett's broth in a $150 \mathrm{~mL}$ conical flask and then incubated at $30^{\circ} \mathrm{C}$ for $72 \mathrm{~h}$ in a rotary shaker with $130 \mathrm{rpm}$ (Remi, India). One $\mathrm{mL}$ of this pre-grown culture was homogenized and used as seed inoculums in all experiments. The production medium was prepared by adding $20 \mathrm{~mL}$ Vogel's minimal medium (22), $3 \mathrm{~g}$ yeast extract and $10 \mathrm{~g}$ Walsath cellulose (85\% phosphoric acid swollen), and finally made up to $1 \mathrm{~L}$ with distilled water. The Vogel's minimal medium containing the following composition in $\mathrm{g} / \mathrm{L}$ of $50 \mathrm{X}$ salts: Water, $750 \mathrm{ml}$; $\mathrm{Na}_{3}$ citrate. $2 \mathrm{H}_{2} \mathrm{O}, 130 ; \mathrm{KNO}_{3}, 126 ;\left(\mathrm{NH}_{4}\right) \mathrm{H}_{2} \mathrm{PO}_{4}, 144 ; \mathrm{KH}_{2} \mathrm{PO}_{4}$, $80 ; \mathrm{MgSO}_{4} .7 \mathrm{H}_{2} \mathrm{O}, 10 ; \mathrm{CaCl}_{2} .2 \mathrm{H}_{2} \mathrm{O}, 5 \mathrm{~g}$ in $20 \mathrm{~mL}$ distilled water, add drop wise; trace elements solution, $5 \mathrm{ml}$; biotin solution $(0.1 \mathrm{mg} / \mathrm{ml}), 2.5 \mathrm{~mL}$ and no adjustment of $\mathrm{pH}$ was necessary or desirable. Trace elements have composition of following recipe: Distilled water, $95 \mathrm{ml}$; Citric acid. $\mathrm{H}_{2} \mathrm{O}, 5 \mathrm{~g}$; $\mathrm{ZnSO}_{4} .7 \mathrm{H}_{2} \mathrm{O} 5 \mathrm{~g}$;
$\mathrm{Fe}\left(\mathrm{NH}_{4}\right)_{2}\left(\mathrm{SO}_{4}\right)_{2} .6 \mathrm{H}_{2} \mathrm{O}, 1 \mathrm{~g} ; \mathrm{CuSO}_{4} .5 \mathrm{H}_{2} \mathrm{O}, 250 \mathrm{mg} ; \mathrm{MnSO}_{4} \cdot \mathrm{H}_{2} \mathrm{O}$, $50 \mathrm{mg} ; \mathrm{H}_{3} \mathrm{BO}_{3}, 50 \mathrm{mg} ; \mathrm{Na}_{2} \mathrm{MoO}_{4} \cdot 2 \mathrm{H}_{2} \mathrm{O}, 50 \mathrm{mg}$. This medium was prepared separately, autoclaved and stored at $4^{\circ} \mathrm{C}$ in a refrigerator until the use. The above seed inoculum $(1 \mathrm{~mL})$ was introduced into $50 \mathrm{~mL}$ production medium in a $250 \mathrm{~mL}$ conical flask and then incubated at $30^{\circ} \mathrm{C}$ for $120 \mathrm{~h}$ a rotary shaking of $130 \mathrm{rpm}$. The culture broth was withdrawn aseptically at periodic intervals, filtered through Whatman number one filter paper and then centrifuged at $6000 \mathrm{rpm}$ for $15 \mathrm{~min}$. The culture supernatant was used as enzyme source.

\section{Study on the effect of culture conditions}

A study on the influence of different nutrients include carbon, nitrogen, sulfur, phosphorus and detergents on endoglucanase synthesis was examined by replacing appropriate sources in the above production medium. The effect of $\mathrm{pH}$ on endoglucanase production was studied by incubating culture in production medium at different initial $\mathrm{pH}$ (5-8.5) under shaking condition at $30^{\circ} \mathrm{C}$. The culture broth was also subjected to incubate at different temperature $\left(20,26,30\right.$ and $\left.37^{\circ} \mathrm{C}\right)$ to study on the effect of incubation temperature for endoglucanase synthesis. The cell-fee culture supernatants were used to estimate enzyme activity.

\section{Endoglucanase assay}

Endoglucanase activity in culture supernatant was determined according to Mandels et al. (12). A reactive mixture of $0.5 \mathrm{~mL}$ of $1 \%(\mathrm{w} / \mathrm{v})$ carboxymethyl cellulose (CMC, high viscosity, HiMedia, India) solution in $0.1 \mathrm{M}$ citrate buffer $(\mathrm{pH}$ 4.8 ), and $0.5 \mathrm{~mL}$ of culture supernatant was incubated at $50^{\circ} \mathrm{C}$. After incubation for $30 \mathrm{~min}$ the reducing sugars released were assayed by adding $1 \mathrm{~mL}$ of 3,5-dinitrosalicyclic acid (DNSA reagent). Controls were prepared with 10 min boiled enzyme. One unit of endoglucanase activity was expressed as the amount of enzyme required to release $1 \mu \mathrm{mol}$ reducing sugars per $\mathrm{mL}$ under the above assay conditions by using glucose as standard curve.

\section{RESULTS AND DISCUSSION}

The cellulase producing microbes have been isolated from decaying wood, forest residues and decomposed leaf in soil (18). Fully decomposed leaves and grasses in soil served a good resource for isolating cellulolytic $S$. albogriseoulus C2221 and S. nitrosporeus N2-14 (20), and Streptomyces sp. strain M7a \& strain M7b (17) using microcrystalline cellulose. Thus, we noted a decomposed nature of lignocellulosic residues (leaf, stalks and stems of garden plants) in garden soil from where cellulolytic microorganisms isolated for our study. Morphological and biochemical properties of these isolates studied, indicating closely resemblances with Streptomyces groups as represented in Bergey's manual. Accordingly, the 
isolated microbial strains assigned to be named as Streptomyces sp. BRC1 and Streptomyces sp. BRC2 in this study. The traditional morphological and biochemical methods used for the identification of aerobic actinomycetes are laborious, timeconsuming and often require a series of specialized tests at species level confirmation (1).

Streptomycetes $\mathrm{sp}$. with potential cellulolytic activity subjected to produce endoglucanase in liquid culture and a study on the effect incubation time on enzyme yield is depicted in Fig. 1. It observed that both Streptomyces isolates gradually raised endoglucanase synthesis and reached maximum activity (6.4$6.6 \mathrm{U} / \mathrm{mL}$ ) at $72-88 \mathrm{~h}$, after that enzyme activity slowly decreased. Similar results have been found in S. flavogriseus (7), S. nitrosporeus $(20)$ and $S$. albaduncus $(5,6)$ for endoglucanase production in broth culture. At initial growth phase Streptomyces sp. would not prefer to use cellulose powder as a sole carbon source due to availability of other enriched simple nutrients in growth media. Therefore, microorganisms may be desired to excrete cellulase for hydrolyzing the cellulose only if other media ingredients become exhausted.

Comparison in terms of enzyme activity is difficult to establish because the prokaryotic cellulases may present very different action from those of fungi, with best temperature and $\mathrm{pH}$ varying among them (8). Harchand and Singh (6) also investigated a profound effect of $\mathrm{pH}$ on cellulase activity of $S$. albaduncus. As shown in Figs. 2 and 3, we found that the $\mathrm{pH}$ and temperature optima for endoglucanase productivity of both isolates were 7-7.5 $(7.9 \mathrm{U} / \mathrm{mL})$ and $26^{\circ} \mathrm{C}(7.1 \mathrm{U} / \mathrm{mL})$ respectively. Beyond this limit of $\mathrm{pH}$ and temperature these isolates did not show substantial enzyme activity. Similarly, Streptomyces sp. F2621 (19) and S. albogriseous (20) also

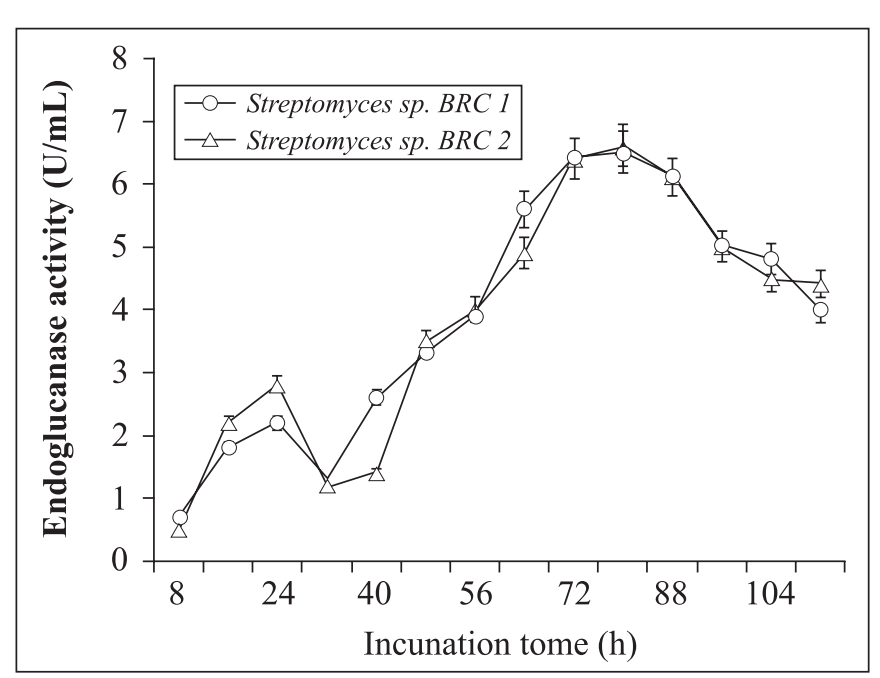

Figure 1. Effect of incubation time on endoglucanase production. exhibited maximum endoglucanase activity at $26-30^{\circ} \mathrm{C}$ with initial $\mathrm{pH}$ of 6.5-7.0.

To maximize endoglucanase yield, the effect of additional carbon supplements in production medium have examined and are presented in Table 1. Among these, starch and maltose repressed endoglucanase production by Streptomyces sp. $\mathrm{BRC} 1$ and $\mathrm{BRC} 2$ respectively and its activity further reduced to $80 \%$. Glucose and cellobiose showed as good inducers to form endoglucanase by these isolates. In addition, cellulose and carboxymethyl cellulose also exhibited extensive role to enzyme yield. Apart from these, other carbon sources did not show a

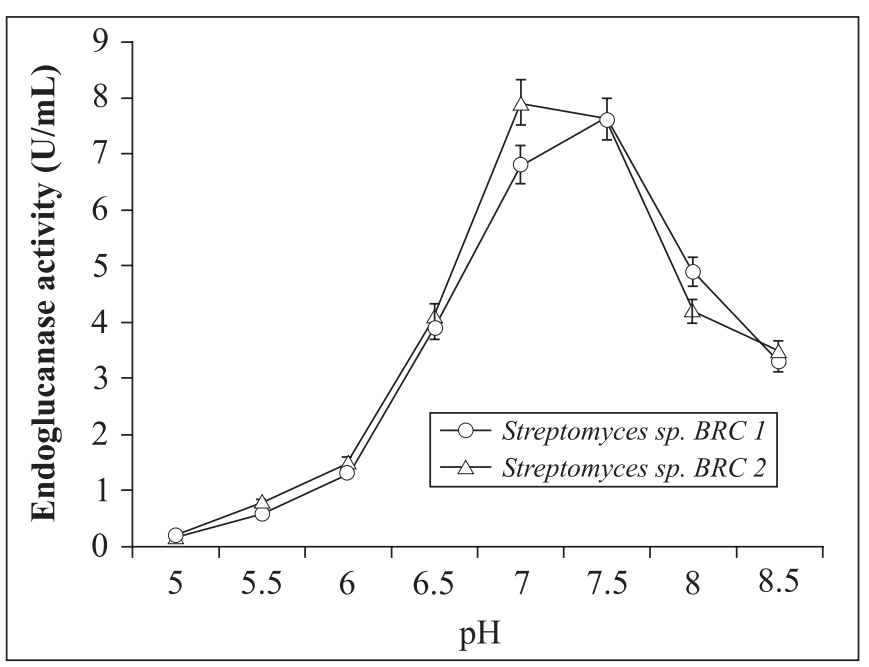

Figure 2. Effect of $\mathrm{pH}$ on endoglucanase production.

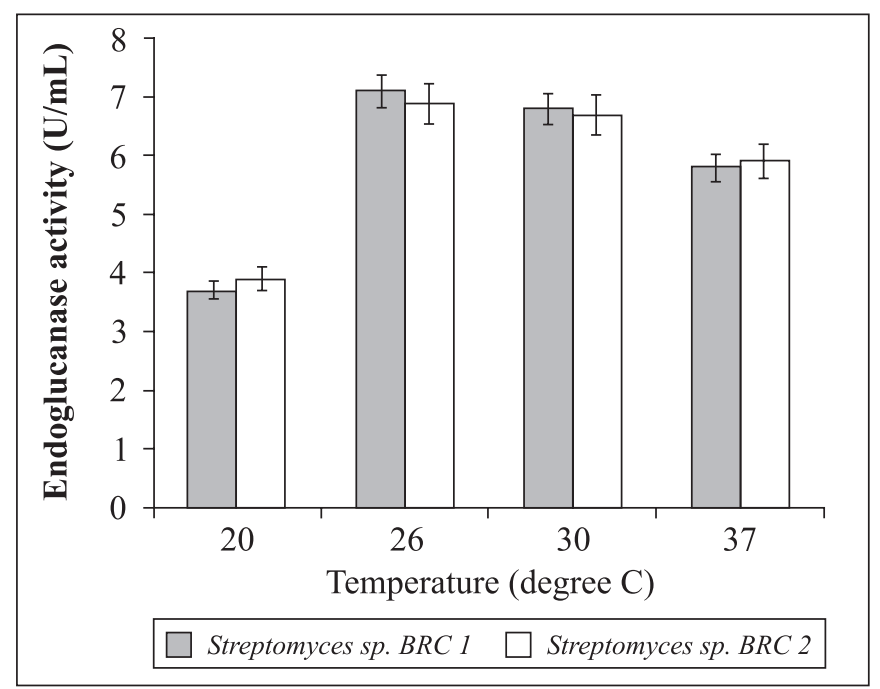

Figure 3. Effect of incubation temperature on endoglucanase production. 
Table 1. Effect of different carbon sources (1\%,w/v) on endoglucanase production by Streptomyces sp. BRC1 and BRC2 isolates under shaking condition.

\begin{tabular}{lcc}
\hline Carbon source & \multicolumn{2}{c}{ Endoglucanase activity $(\mathrm{U} / \mathrm{mL})$} \\
\cline { 2 - 3 } & $\begin{array}{c}\text { Streptomyces sp. } \\
\text { BRC1 }\end{array}$ & $\begin{array}{c}\text { Streptomyces } \mathbf{s p} . \\
\text { BRC2 }\end{array}$ \\
\hline Xylose & $4.20 \pm 0.5$ & $3.05 \pm 0.5$ \\
Inulin & $3.88 \pm 0.4$ & $4.44 \pm 0.4$ \\
Glucose & $6.65 \pm 0.7$ & $8.05 \pm 0.7$ \\
CMC & $3.55 \pm 0.4$ & $4.07 \pm 0.5$ \\
Cellulose & $3.98 \pm 0.5$ & $4.00 \pm 0.6$ \\
Cellobiose & $5.64 \pm 0.6$ & $10.0 \pm 0.7$ \\
Starch & $2.13 \pm 0.4$ & $3.36 \pm 0.4$ \\
Maltose & $3.61 \pm 0.4$ & $1.75 \pm 0.4$ \\
Fructose & $2.77 \pm 0.3$ & $2.40 \pm 0.6$ \\
Sucrose & $2.96 \pm 0.4$ & $3.38 \pm 0.5$ \\
Lactose & $3.62 \pm 0.5$ & $3.11 \pm 0.4$ \\
\hline
\end{tabular}

The enzyme activity in culture supernatant was determined after $84 \mathrm{~h}$ incubation.

significant improvement on enzyme productivity. The extracellular endoglucanase synthesis is cyclic dependent and therefore subject to catabolite repression by soluble sugar accumulation. Cellulase synthesis of S. reticuli is regulated by inductive and repressive action of metabolizable sugars on catalytic domain (16). Cellotriose and cellotetraose for Streptomyces sp. (4), and cellobiose and crystalline cellulose for Trametes trogii (10) are investigated as inducers for endoglucanase production. Therefore, only some soluble sugars as reported here are suggested for optimistic enzyme synthesis in the production media.

Considering the effect nitrogen source on endoglucanase formation as shown in Table 2, we found that meat extract and tryptone served as intensive sources to Streptomyces sp. BRC1. Yeast extract suited for enhanced production of this enzyme by Streptomyces sp. BRC2. When the production media incorporated with different inorganic nitrogen source, $\mathrm{KNO}_{3}$ $(6.36 \mathrm{U} / \mathrm{mL})$ and $\left(\mathrm{NH}_{4}\right)_{2} \mathrm{SO}_{4}(6.65 \mathrm{U} / \mathrm{mL})$ supported to bring more endoglucanase activity by Streptomyces sp. BRC1 and BRC2 respectively. Yeast extract for Streptomyces sp. F2621 (19) whereas $\mathrm{KNO}_{3}$ for filamentous fungi are reported as potential nitrogen sources for endoglucanase production (18).

Among phosphate and sulfur sources examined as shown in Table 3, $\mathrm{NaH}_{2} \mathrm{PO}_{4}$ for Streptomyces sp. BRC1 and $\mathrm{KH}_{2} \mathrm{PO}_{4}$ for Streptomyces sp. BRC2 found to be good for improved endoglucanase activity. Under the same culture conditions, enzyme synthesis by both isolates profoundly improved in culture broth when incorporated with $\mathrm{MgSO}_{4}$ and $\left(\mathrm{NH}_{4}\right)_{2} \mathrm{SO}_{4}$.
Table 2. Effect of different nitrogen (1\%, w/v) sources on endoglucanase production by Streptomyces sp. BRC1 and BRC2 isolates under shaking condition. The concentration of organic nitrogen and inorganic nitrogen sources was $0.3 \%$ and $0.03 \%$ (w/v), respectively.

\begin{tabular}{lcc}
\hline Nitrogen source & \multicolumn{2}{c}{ Endoglucanase activity $(\mathrm{U} / \mathrm{mL})$} \\
\cline { 2 - 3 } & $\begin{array}{c}\text { Streptomyces } \mathbf{s p} . \\
\text { BRC1 }\end{array}$ & $\begin{array}{c}\text { Streptomyces } \mathbf{s p} . \\
\text { BRC2 }\end{array}$ \\
\hline Yeast extract & $4.07 \pm 0.3$ & $7.77 \pm 0.5$ \\
Meat extract & $7.86 \pm 0.5$ & $6.93 \pm 0.5$ \\
Proteose peptone & $7.49 \pm 0.6$ & $4.84 \pm 0.4$ \\
Casein & $7.03 \pm 0.5$ & $7.04 \pm 0.6$ \\
Tryptone & $7.86 \pm 0.5$ & $5.63 \pm 0.4$ \\
$\mathrm{NH}_{4} \mathrm{Cl}$ & $5.27 \pm 0.4$ & $6.38 \pm 0.5$ \\
$\left(\mathrm{NH}_{2}\right)_{4} \mathrm{SO}_{4}$ & $6.27 \pm 0.4$ & $6.66 \pm 0.5$ \\
$\mathrm{KNO}_{3}$ & $6.38 \pm 0.5$ & $5.00 \pm 0.4$ \\
$\left(\mathrm{NH}_{2}\right)_{4} \mathrm{HPO}_{4}$ & $5.18 \pm 0.4$ & $6.05 \pm 0.5$ \\
\hline
\end{tabular}

The enzyme activity in culture supernatant was determined after $84 \mathrm{~h}$ incubation.

Table 3. Effect of different phosphate and sulfate sources $(0.03 \%$, w/v) on endoglucanase production by Streptomyces sp. BRC1 and BRC2 isolates under shaking condition.

\begin{tabular}{lcc}
\hline & \multicolumn{2}{c}{ Endoglucanase activity $(\mathrm{U} / \mathrm{mL})$} \\
\cline { 2 - 3 } & $\begin{array}{c}\text { Streptomyces sp. } \\
\text { BRC1 }\end{array}$ & $\begin{array}{c}\text { Streptomyces sp. } \\
\text { BRC2 }\end{array}$ \\
\hline Phosphate source & & \\
$\mathrm{Na}_{2} \mathrm{HPO}_{4}$ & $6.10 \pm 0.5$ & $7.12 \pm 0.5$ \\
$\mathrm{NaH}_{2} \mathrm{PO}_{4}$ & $10.2 \pm 0.7$ & $6.70 \pm 0.5$ \\
$\mathrm{~K}_{2} \mathrm{HPO}_{4}$ & $7.75 \pm 0.5$ & $6.12 \pm 0.4$ \\
$\mathrm{KH}_{2} \mathrm{PO}_{4}$ & $8.74 \pm 0.6$ & $9.28 \pm 0.7$ \\
$\left(\mathrm{NH}_{2}\right)_{4} \mathrm{HPO}_{4}$ & $8.97 \pm 0.6$ & $5.18 \pm 0.4$ \\
$\mathrm{Sulfate} \mathrm{source}_{(\mathrm{NH} 2)_{4} \mathrm{SO}_{4}}$ & \\
$\mathrm{FeSO}_{4}$ & $6.03 \pm 0.6$ & $7.40 \pm 0.5$ \\
$\mathrm{~K}_{2} \mathrm{SO}_{4}$ & $4.81 \pm 0.5$ & $2.87 \pm 0.4$ \\
$\mathrm{Na}_{2} \mathrm{SO}_{4}$ & $2.36 \pm 0.4$ & $5.31 \pm 0.5$ \\
$\mathrm{MgSO}_{4}$ & $5.65 \pm 0.5$ & $5.09 \pm 0.5$ \\
\hline
\end{tabular}

The enzyme activity in culture supernatant was determined after $84 \mathrm{~h}$ incubation.

This revealed that the salts with defined concentration can promote the growth of organisms, but not to simulate physiological conditions corresponding to synthesis of a specific extracellular enzyme in production medium. Obviously, 
it suggested that adding relevant nutrient supplements with optimistic concentrations are desirable to bring a favorable condition for these Streptomyces isolates so as to increase endoglucanase yield.

Apart from nutrient and environmental factors, surfactants are considered as good inductive sources while production media optimization. Surfactants are used to increase the permeability of bacterial cell membrane by which enhancing membrane transport and excretion of extracellular enzymes into the production media (13). Consequently, the maximum endoglucanase production was achieved $(11.93 \mathrm{U} / \mathrm{mL})$ at $84 \mathrm{~h}$ by both isolates when the production medium supplemented with Tween-80 (Table 4). Additionally, Tween-20, Tween-40, sodium deoxycholate and SDS also exhibited a stimulatory effect (1.6-fold increase) for endoglucanase production. It pointed out the detergents are comparatively better ingredient than use of other supplements for Streptomyces cellulase synthesis.

Table 4. Effect of different surfactants $(0.003 \%$, w/v) on endoglucanase production by Streptomyces sp. BRC1 and $\mathrm{BRC} 2$ isolates under shaking condition.

\begin{tabular}{lcc}
\hline \multirow{2}{*}{ Detergent } & \multicolumn{2}{c}{ Endoglucanase activity $(\mathrm{U} / \mathrm{mL})$} \\
\cline { 2 - 3 } & $\begin{array}{c}\text { Streptomyces } \mathbf{s p} . \\
\text { BRC1 }\end{array}$ & $\begin{array}{c}\text { Streptomyces } \mathbf{s p} \\
\text { BRC2 }\end{array}$ \\
\hline Tween-20 & $11.1 \pm 0.7$ & $9.06 \pm 0.5$ \\
Tween-40 & $9.53 \pm 0.5$ & $7.58 \pm 0.5$ \\
Tween-80 & $11.93 \pm 0.4$ & $10.78 \pm 0.6$ \\
Sodium deoxycholate & $11.28 \pm 0.7$ & $9.30 \pm 0.6$ \\
SDS & $10.64 \pm 0.6$ & $10.73 \pm 0.5$ \\
Clove oil & $9.62 \pm 0.9$ & $10.10 \pm 0.8$ \\
\hline
\end{tabular}

The enzyme activity in culture supernatant was determined after 84 days incubation.

\section{CONCLUSIONS}

Optimization of fermentation media ingredients and environmental factors for enzyme production is a more convenient and effective strategy, compared to other recent approaches like molecular techniques, to manifest the physiological characteristics to synthesis endoglucanase (10, 20). Among different media ingredients optimized, detergents in production medium are showed a reasonable inductive response on endoglucanase production. Both Streptomyces strains comparatively studied for evaluating their independent capacities on cellulase formation, it divulging a new insight for a strong suitability of these isolates for endoglucanase production in large scale fermentation. A profitable enhancement of endoglucanase activity is recorded as $12 \mathrm{U} / \mathrm{mL}$ at $84 \mathrm{~h}$ with 1.6-fold increase in the production yield. Thus, the results enlighten the optimized environmental and cultural conditions are prominent needs for producing extracellular endoglucanase by these soil isolates. These strains are promising for industrial application since they grow quickly in broth condition in simple and of a low cost process to enhance production yield, and the secreted enzymes are frequently required for industrial applications. Moreover, the important noteworthy of these strains is that they are capable of producing endoglucanase alone with more yield apart from other cellulase components compared. Therefore, it is thought to be considered as potential industrial candidate for effective saccharification process.

\section{ACKNOWLEDGEMENTS}

The authors are thankful to Vice-Chancellor and Registrar of Gujarat Vidyapith, Ahmedabad for permitting to carry out this investigation. This work was financially supported by University Grants Commission, New Delhi, India.

\section{RESUMO}

\section{Produção de endoglucanase por cepas nativas de Streptomyces em fermentação submersa}

A celulase é um sistema enzimático complexo, produzido comercialmente a partir de fungos filamentosos através de cultivo em estádio sólido e submerso. Tem uma grande aplicação na indústria têxtil e de alimentos e bebidas no processo de sacarificação. Nesse estudo, examinou-se a atividade celulolítica, especialmente de englucanase, de 26 cepas de Streptomyces isoladas de solo, incluindo duas cepas selecionadas por sua atividade celulolítica no ágar Bennett. Para estimular a produção de englucanase em meio de cultura, diferentes condições de cultivo, incluindo fonte de carbono e nitrogênio e condições de crescimento, foram avaliadas. A atividade máxima de glucanase $(11,25$ a $11,90 \mathrm{U} / \mathrm{mL})$ foi obtida em 72-88h em meio de cultura contendo Tween-80, seguido por fontes de fosfato. Ambas as cepas celulolíticas de Streptomyces produziram quase a mesma quantidade de enzima em todos os experimentos. Entretanto, o efeito dos ingredientes do meio na indução da glucanase divergiu de acordo com a cepa.

Palavras-chave: endoglucanase, Streptomyces, fermentação submersa, otimização de meios, celulase, CMCase.

\section{REFERENCES}

1. Andrew, E.C.; Paul, R.M. (2003). Rapid identification of filamentous actinomycetes to the genus level using genus-specific 16S rRNA gene restriction fragment patterns. Int. J. Syst. Evol. Microbiol., 53, 1907-1915. 
2. Chellapandi, P.; Himanshu, M.J. (2001). Optimizing condition for enhanced endoglucanase production from Streptomyces sp. BRC1. National Seminar on Microbial Technology, Coimbature, India, p.34

3. Chellapandi, P.; Himanshu, M.J. (2002). Culture condition for enhanced endoglucanase production by the native strains of Streptomyces sp. International conference of SAARC countries on Biotechnology in Environment, Agriculture and Industry, Karad, India, p.80.

4. Godden, B.; Legon, T.; Helvenstein, P.; Penninckx, M. (1989). Regulation of the production of hemicellulolytic and cellulolytic enzymes by a Streptomyces sp. growing on lignocelluloses. J. Gen. Microbial., 135, 285-292.

5. Harchand, R.K.; Singh, S. (1994). Catabolite repression of cellulase biosynthesis in Streptomyces albaduncus. J. Basic. Microbiol., 34 (6), 371-378.

6. Harchand, R.K.; Singh, S. (1997). Characterization of cellulase complex of Streptomyces albaduncus. J. Basic. Microbiol., 37 (2), 93-103.

7. Ishaque, M.; Kluepfel, D. (1980). Cellulase complex of a mesophilic Streptomyces strain. Can. J. Microbiol., 26 (2), 183-189.

8. Heck, J.X.; Hertz, P.F.; Ayub, M.A.Z. (2002). Cellulase and xylanase production by isolated Amazon Bacillus strains using soya been industrial residue based solid-state cultivation. Braz. J. Microbiol., 33, 213-218.

9. Kluepfel, D.; Shareck, F.; Mondau, F.; Morosoli, R. (1986). Characterization of cellulase and xylanase activities of Streptomyces lividans. Appl. Microbiol. Biotechnol., 24, 230-234.

10. Levin, L.; Forchiassin, F. (1995). Effect of carbon and nitrogen sources on the cellulolytic activity of Trametes trogii. Rev. Argent. Microbiol., 27 (1), 11-20.

11. Mackenzie, C.R.; Bilous, D.; Schneider, H.; Johnson, K.G. (1987). Induction of cellulolytic and xylanolytic Enzyme Systems in Streptomyces sp. Appl. Environ. Microbiol., 53 (12), 2835-2839.
12. Mandels, M.; Andreotti, R.; Roche, C. Measurement of saccharifing cellulase. Biotechnol. Biogen. Symp., 6: 21-31, 1976.

13. Okeke, B.C.; Obi, S.K.C. (1993). The production of cellulolytic and xylanolytic enzymes by an Anthrographiae sp. World J. Microbiol. Biotechnol., 9, 345-349.

14. Roamana, T.; Rajoka, M.I.; Malik, K.A. (1999). Production of cellulases and hemicellulases by an anaerobic mixed culture from lignocellulosic biomass. World J. Microbiol. Biotechnol., 6, 39-45.

15. Roberto, D.S.; Ellen, S.L.; Carolina, W.; Mariana, M.; Youg, K.P.; Eleni, G. (2005). Production of xylanase and CMCase on solid-state fermentation in different residues by Theroascus aurantiacus MIEHE. Braz. J. Microbiol., 36, 235-241.

16. Schrempf, H.; Walter, S. (1995). The cellulolytic system of Streptomyces reticuli. Int. J. Biol. Macromol., 17 (6), 353-355.

17. Semedo, L.T.; Gomes, R.C.; Bon, E.P.; Soares, R.M.; Linhares, L.F.; Coelho, R.R. (2000). Endocellulase and exocellulase activities of two Streptomyces strains isolated from a forest soil. Appl. Biochem. Biotechnol., 84, 267-276.

18. Smruti, P.; Rao, K.K.; Krishna, M. (1995). The production of betaglucosidase by Aspergillus terreus. Curr. Microbiol., 30, 255-258.

19. Tuncer, M.; Kuru, A.; Isikli, M.; Sahin, N.; Celenk, F.G. (2004). Optimization of extra-cellular endoxylanase, endoglucanase and peroxidase production by Streptomyctes sp. F2621 isolated in 17 Turkey. J. Appl. Microbiol., 97 (4), 783-791.

20. Van Zyl, W.H. (1985). A Study of the cellulases produced by three mesophilic actinomycetes grown on bagasse as substrate. Biotechnol. Bioengi., 27 (9), 1367-1373

22. Vogel, H.J. (1956). A convenient growth medium for Neurospora crassa. Microbial. Genet. Bull., 13, 42-43.

23. http://www.udel.edu/chem/bahnson/chem645/websites/Heaton/ 